\title{
Nutritional and Microbiological Characteristics of Snakehead Fish Flour (Channa Striata) and Its Modification as Weight Enhancing Supplements for Children with Tuberculosis
}

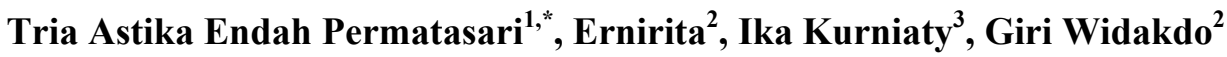 \\ ${ }^{1}$ Faculty of Medicine and Health, Universitas Muhammadiyah Jakarta, Indonesia \\ ${ }^{2}$ Faculty of Nursing Science, Universitas Muhammadiyah Jakarta, Indonesia \\ ${ }^{3}$ Faculty of Engineering, Universitas Muhammadiyah Jakarta, Indonesia
}

Received December 9, 2020; Revised June 4, 2021; Accepted July 19, 2021

\section{Cite This Paper in the following Citation Styles}

(a): [1] Tria Astika Endah Permatasari, Ernirita, Ika Kurniaty, Giri Widakdo , "Nutritional and Microbiological Characteristics of Snakehead Fish Flour (Channa Striata) and Its Modification as Weight Enhancing Supplements for Children with Tuberculosis," Food Science and Technology, Vol. 9, No. 3, pp. 45 - 57, 2021. DOI: 10.13189/fst.2021.090301.

(b): Tria Astika Endah Permatasari, Ernirita, Ika Kurniaty, Giri Widakdo (2021). Nutritional and Microbiological Characteristics of Snakehead Fish Flour (Channa Striata) and Its Modification as Weight Enhancing Supplements for Children with Tuberculosis. Food Science and Technology, 9(3), 45 - 57. DOI: 10.13189/fst.2021.090301.

Copyright $\mathrm{O} 2021$ by authors, all rights reserved. Authors agree that this article remains permanently open access under the terms of the Creative Commons Attribution License 4.0 International License

\begin{abstract}
The variation in the use of snakehead fish flour as food supplement continues to increase. This study aims to provide solutions to improve the nutritional intake of children with TB by analyzing the nutrient content in snakeheaded fish flour (Channa striata) as weight enhancing in Indonesia. Snakehead fish (Channa Striata) processing is divided into three types of supplements: original snakehead fish supplement (without any additional food), snakehead supplement which is varied with tofu dregs, and fish supplement which varied with turmeric extract. The results showed that snakehead fish has a yield of about $2.38-2.97 \%$, and an edible portion of snakehead fish ranged from $50.35-55.12 \%$. Snakeheaded fish contains $0.7 \%$ albumin extracted using a Hydrochloric Acid (HCL) solvent at a concentration of $0.25 \mathrm{M}$. Among the three types of flour, the nutritional content of the original cork fish meal showed the best results. The nutritional composition produced in snake-headed fish flour is $11.05 \%$ water content, $5.13 \%$ ash content, $79.62 \%$ protein, $4.93 \%$ fat content, and energy of $363 \mathrm{kcal}$. The protein content of snakehead fish flour is included in the Quality or Grade I (good) category based on the quality standard of fish flour (Indonesian National Standard 01-2715-1996). The results of the microbiological analysis showed that the
\end{abstract}

snakeheaded fish flour product was free from contamination by pathogenic bacteria include Escherichia coli, Salmonella, and coliform bacteria. The high protein and energy content found in cork fish meals can be used as a basis to develop into a weight-enhancing supplement for children with tuberculosis.

Keywords Children, Snakehead (Channa striata), Tuberculosis, Weight Enhancing Supplement

\section{Introduction}

The morbidity and mortality of children due to tuberculosis increased significantly during the Covid-19 pandemic [1]. Tuberculosis (TB) and Covid-19 are infectious diseases that attack primarily the lungs that can interact synergistically to drop the immune system [2]. Tuberculosis is caused by the bacillus Mycobacterium tuberculosis and can worsen the health condition by Covid-19 of children with tuberculosis [3][4]. There are two types of tuberculosis, namely latent tuberculosis and active tuberculosis. Latent tuberculosis occurs when people are infected with Mycobacterium tuberculosis, but 
their immune system can protect them. But active tuberculosis occurs when the infection is no longer controlled by the immune system and can occur at any time after bacterial infection. The potential occurrence from latent tuberculosis to active tuberculosis later is about $5 \%$ to $10 \%$ in a healthy population and increases to about $50 \%$ in people with severe immune system damage such as infected Covid-19 or human immunodeficiency virus (HIV) infection [5]. Therefore, WHO works together with many countries in reaching the goal of zero TB deaths among children worldwide [6]. One of the global strategic actions which develop to reduce the health worse effect of children with tuberculosis is to improve malnutrition accomplishing other factors such as HIV, poverty, and sanitation and hygiene [1][6][7][8].

The relationship between malnutrition and tuberculosis has been scientifically proven consistently [5][9][10]. Malnutrition can exacerbate children with tuberculosis or delaying recovery by suppressing immune function that plays a role in controlling Mycobacterium tuberculosis infection [7]. Fulfillment of nutritional adequacy and development of the adaptive immune system in children are determined by exclusive breastfeeding from birth to 6 months of age [11][12][13][14]. Conversely, children with tuberculosis are at risk of experiencing malnutrition due to decreased appetite and intake, nutrient malabsorption, and increased metabolic [7][15][16]. Chiang et al showed that weight gain optimizes $\mathrm{TB}$ treatment in children with tuberculosis [15]. In line with that study, a study using data in the TB clinic of Hallym University Kangdong Sacred Heart Hospital, Seoul, Korea, showed that nutritional status significantly correlated with the optimization of treatment for pulmonary tuberculosis (PTB) patients [16]. In addition, oral nutritional supplement consumption such as food, protein/energy supplements, or micronutrients can increase their body weight [5][17][18]. A cross sectional study in China by Ren et al showed that TB patients have insufficient daily energy-protein intake compared with the Chinese Dietary Reference Intakes (DRIs) 2013. Also they are insufficient of many micronutrients daily intake [19]. Macronutrients including carbohydrate and fat are converted to energy, while protein and some fat are used to make structural and functional components of human tissue. Based on the Indonesian Dietary Referencw Intake, the energy and protein needs for boys aged 10-18 years are 2000-2650 kcal and 50-75 g per person per day, respectively. Meanwhile, the energy and protein requirements for girls in the same age range are 1900-2100 kcal and 55-65 g per person per day [20]. While micronutrients (vitamins and minerals) are consumed in small amounts and are essential for metabolic processes. Macronutrients and micronutrients work together to contribute to tissue regeneration and cellular integrity [17].

Protein supplement provides essential amino acids
(EAAs) that are highly recommended for increasing body weight and immune system in children with tuberculosis [5]. EAAs are fulfilled of most energy substrates in catabolic conditions and serve as a fuel for protein synthesis and cell growth through anabolic conditions. Also, EAAs play a role in facilitating the gut microbiota in the gastrointestinal tract required for metabolic function and the immune system [21][22]. In addition, the need for albumin as the main protein is also needed in increasing the immunity of children with tuberculosis. A study by Shingdang et al showed that serum albumin/globulin ratio significantly correlation between TB patient and control [23]. One of the foods that contain high albumin is snakehead fish. Snakehead fish (Channa striata) has a very high albumin fraction of protein compared to other animal protein sources, reaching more than 50\% [24]. Previous studies have shown that consumption of snakehead fish supplements can increase serum albumin levels and improve the nutritional status [24][25][26][27]. Snakehead fish supplement can significantly accelerate the treatment of tuberculosis patients [25]. A true Experimental in Jember District and Situbondo District, East Java, Indonesia showed that Channa striata supplementation can improve the Body Mass Index (BMI) of tuberculosis patient in Indonesia significantly than patients who were not given this supplements [26].

Snakehead fish (Channa Striata) is a freshwater fish native to South and Southeast Asia. In various regions in Indonesia, this fish is available in abundance, cheap, and easy to cultivate. This fish content the high albumin that can be developed as neutracetical products [28][29][30]. Asikin and Kusumaningrum (2018) grouped the size of Snakehead into three categories, namely small sizes weighing less than $600 \mathrm{~g}$, medium for weighing between $600-900 \mathrm{~g}$, and large for fish weighing more than $900 \mathrm{~g}$. The yield of this fish is about $3 \%$ and about $50-55 \%$ edible portion. Also, this study showed that this fish contained about $13 \%$ moisture content, $23 \%$ ash, $64 \%$ protein, $2 \%$ fat, and $18 \%$ albumin [31]. Nurilmala et al in 2020 showed that protein content of Snakehead is determined by the processing method. Protein content of Stripped Snakehead, namely fresh extract is $11.62 \pm 0.17$ $\mathrm{mg} / \mathrm{g}$, boiled extract $6.28 \pm 0.57 \mathrm{mg} / \mathrm{g}$, and precipitated extract is $105.23 \pm 0.44 \mathrm{mg} / \mathrm{g}$ [30]. Processing of this fish in the health sector can be made of snakehead fish flour which is an ingredient in the manufacture of supplements for children with tuberculosis or malnutrition. It is used as the main raw material, formulated with other foods that are high in nutritional content, as well as fortified by essential nutrients [32]. Based on the nutritional and microbiological analysis that has been carried out in previous studies in Indonesia, the quality of snakehead fish flour (Channa striata) has met the quality requirements of fish meal based on the Indonesian National Standard (Standar Nasional Indonesia 
01-2715-1996) which is an improvement of the revision of SNI 01-2715-1992 [33]. Therefore, the use of snakehead fish flour as supplements including for weight enhancing supplements for Children with Tuberculosis consistently developed in line with the increasing prevalence of TB worldwide [25][26][34][27].

TB has a wide spectrum of exposure which can affect anyone, anywhere. WHO an estimated 10.0 million (range, 8.9-11.0 million) people fell ill with TB in 2019, where children (aged $<15$ years) accounted for $12 \%$ of the people who developed TB in 2019. In order to act faster to end TB and meet the SDG targets, The World Health Assembly adopted the World Health Organization (WHO) General Programme of Work (GPW-13) 2019-2023 as commit to provide diagnosis and treatment with the aim of successfully treating 3.5 million children with $\mathrm{TB}$, and 115000 children with drug-resistant tuberculosis from 2018 to 2022. But, today the world is faced with the pandemic's impact on TB mortality indicate that a $50 \%$ drop in the detection of TB cases over 3 months will cause people dying from TB [1]. The highest contributors to the global increase in TB were India and Indonesia, the two countries that rank first and second in the world in terms of estimated incidence per year. Indonesia as a tropical country is categorized as a tuberculosis-endemi area, where tuberculosis patients suffered from undernutrition [1][26]. In this country, the increase occurred significantly, reaching around $69 \%$, which increased from 331703 in 2015 to 562,049 in 2019 [1]. Of the total TB patients, $0.6 \%$ were in the children group, namely $0.1 \%$ aged less than 1 year, $0.3 \%$ aged $1-4$ years, and $0.2 \%$ aged $5-14 \%$. This condition is a challenge because it refers to the Regulation of the Minister of Health of the Republic of Indonesia Number 67 in 2016 concerning Tuberculosis Control, Indonesia has set a target for a national TB control program, namely elimination by 2035 and a TBC-free Indonesia in 2050 [35]. To achieve this target, cross-sectoral collaboration efforts to address the problem of malnutrition and other risk factors such as social communication, especially overcoming poverty, improve sanitation, and improve education and knowledge of mothers about nutrition since the period of pregnancy as a critical point in the first 1000 days of life [26][36][37][38]. This purpose of study is to analyze the nutritional and microbiological characteristics of snakehead fish flour (Channa striata) and its modification as weight enhancing supplements as one of the solutions offered to treat malnutrition and accelerate treatment for children with tuberculosis.

\section{Material and Methods}

\subsection{Material and Equipment}

Snakehead fish (Channa striata) was obtained from traditional markets in Bekasi, West Java Province,
Indonesia. Its weight is between 600-900 $\mathrm{g}$ (medium size category). The selection of this weight is optimizing the yield and steaming process [31]. Other material includes tofu dregs, and turmeric obtained from the traditional market in West Java. According to Basic Health Research of the Republic of Indonesia in 2018, thus province was categorized as the third-highest rank of TB prevalence in Indonesia [39].

The equipment used in snakehead fish flour processing is a blender, knife, water bath/heater, pan for steaming snakehead fish, oven, sieve, and a digital scale. Nutritional and microbiological characteristics use analysis services in The Laboratory of the Department of Food Science and Technology and Nutrition, Faculty of Agricultural Technology, Bogor Agricultural University (IPB University), West Java Province, Indonesia.

\subsection{Analysis}

\subsubsection{Nutritional and Microbiological characteristics}

The yield calculation is done by weighing the weight of the snakehead fish dry extract divided by the initial weight of meat before extraction, multiplied by $100 \%$. Meanwhile, the calculation of the percentage of the edible portion (EP) is calculated by dividing the weight of fish fillets divided by the weight of whole fish multiplied by $100 \%$ [40]. Analysis of nutritional and microbiological characteristics of snakehead fish flour (Channa Striata) as weight enhancing supplements for children with tuberculosis, and its modification including snakehead fish supplement with tofu dregs, and snakehead supplement with turmeric extract using Laboratorium Departemen Ilmu dan Teknologi Pangan, Fakultas Teknologi Pertanian, Institut Pertanian Bogor (Laboratory of the Department of Food Science and Technology and Nutrition, Faculty of Agricultural Technology, Bogor Agricultural University/IPB University), West Java Province Indonesia. This laboratory is certified by National Accreditation Committee (Komite Akreditasi Nasional) is used with the certified number is 126-19/FL/04/4.4.1/LDITP. The analysis of nutritional characteristics consists of: water content, ash content, protein content, fat content, carbohydrates, crude fiber, energy, and vitamin C. While for microbiological characteristics analyzed total plate count (colony/g), total yeast and mold (colony/g), Salmonella, Escherichia coli, a total of Staphylococcus aureus (colony/g), and coliform bacteria (MPN/g). Furthermore, the results of the analysis compared with fish flour quality requirements by the Indonesian National Standard (SNI 01-2715-1996) are an improvement of SNI 01-2715-1992 revision [33].

\subsubsection{Albumin Content}

Analysis of albumin content is analyzed by High-Performance Liquid Chromatography (HPLC). The albumin levels analyzed were only original snakehead fish 
supplements. The samples were analyzed using the certified laboratory, namely Laboratorium Penguji, Balai Bioteknologi, Badan Pengkajian dan Penerapan Teknologi, Indonesia (The Testing Laboratory, Institute for Biotechnology, Agency for the Assessment and Application of Technology, Indonesia). The certificate number on this analysis of albumin content is 257-SHU-08-2018.

\subsection{Processing Methods and Procedure}

In principle, the processing of three types of snakehead fish flour (original snakehead fish flour, snakehead fish with tofu dregs, and snakehead fish with turmeric extract) in this study is appropriate (Figure 1). The original snakehead fish floor is only used snakehead fish as the main ingredient. For snakehead fish flour modified, added the tofu dregs or turmeric extract. The two types of food ingredients include tofu dregs, and turmeric extract contains high nutrition. Tofu dregs contain high protein, increases albumin levels, and potential to increase the body weight in children with tuberculosis [41][42][42][43]. Likewise, turmeric extract contains polyphenol curcumin that has a role as an antioxidant and anti-inflammatory. It also has health benefits for increasing immunity and appetite sensations [44][45][46].

The process of making snakehead fish flour includes a selection and cleaning of fresh fish, steaming, fish fillets, drying, and sieving [43][47]. The processing methods that are important in the process of making these supplements are steaming and drying. The steaming method is chosen in this study compared to the boiling method because to get optimal yield, protein, and albumin levels from snakehead fish. This process was conducted at a temperature between $60-70^{\circ} \mathrm{C}$ for approximately 50 minutes. Previous studies have proven that this method is the best simple way to maintain nutritional content, especially protein and albumin content of snakehead fish [48][49][50]. The products are heated at $60^{\circ} \mathrm{C}$ for about 8 hours to obtain a dry fish fillet texture. This process can prevent the activity of pathogenic microorganisms and reduce the water content of these products [28]. Furthermore, the dried snakehead fish fillets are mashed, sifted, and ready to pack.

\section{Results}

\subsection{Nutritional Characteristics of Snakeheaded Fish Flour}

The results showed that the snakehead fish has a yield of about $2.38-2.97 \%$, and an edible portion of snakehead fish ranged from 50.35-55.12\%. Table 1 shows the nutritional characteristics of original snakehead fish flour, and its modifications include snakehead fish flour with tofu dregs and snakehead fish flour with turmeric extract. The water content was analyzed by referring to the Indonesian National Standard regarding the Food and Beverage Test Method, namely SNI 01-2891-1992 (Gravimetry), point 5.1. Original snakehead fish flour had the lowest water content $(11.05 \%)$ compared to the other two types of flour, namely snakehead fish flour with tofu dregs $(14.66 \%)$ and snakehead fish flour with turmeric extract $(16.83 \%)$. Also, original snakehead fish flour had the lowest ash content and fat content, namely $5.13 \%$ and $4.93 \%$, respectively, compared to the two types of modified snakehead fish flour. However, for protein content, original snakehead fish flour had the highest content of $79.62 \%$ compared to snakehead fish flour with tofu dregs $(71.11 \%)$ and protein content of snakehead fish flour with turmeric extract $(71.41 \%)$. Of three types of snakehead fish flour, albumin content was only analyzed on the original snakehead fish flour. Based on the results of the analysis using High-Performance Liquid Chromatography (HPLC), the origin snakehead fish flour contained $0.7 \%$ albumin extracted using a Hydrochloric Acid (HCL) solvent at a concentration of 0.25 . Another macronutrient analysis is the analysis of carbohydrate content. Of the three types of snakehead fish flour, the results showed that the original snakehead fish flour and snakehead fish flour with turmeric extract had no carbohydrate content $(0 \%)$. Only snakehead fish flour with tofu dregs showed a small amount of carbohydrate content, namely $0.89 \%$. The crude fiber content in original snakehead fish $(0.66 \%)$ was lower than the crudes fiber content in snakehead fish flour with tofu dregs $(2.52 \%)$ and snakehead fish flour with turmeric extract $(0.83 \%)$. The original snakehead fish flour has the highest energy content that is $363 \mathrm{kcal}$. Meanwhile, the energy content of snakehead fish flour with tofu dregs and snakehead fish flour with turmeric extract is $338 \mathrm{kcal}$ and $337 \mathrm{kcal}$, respectively. 


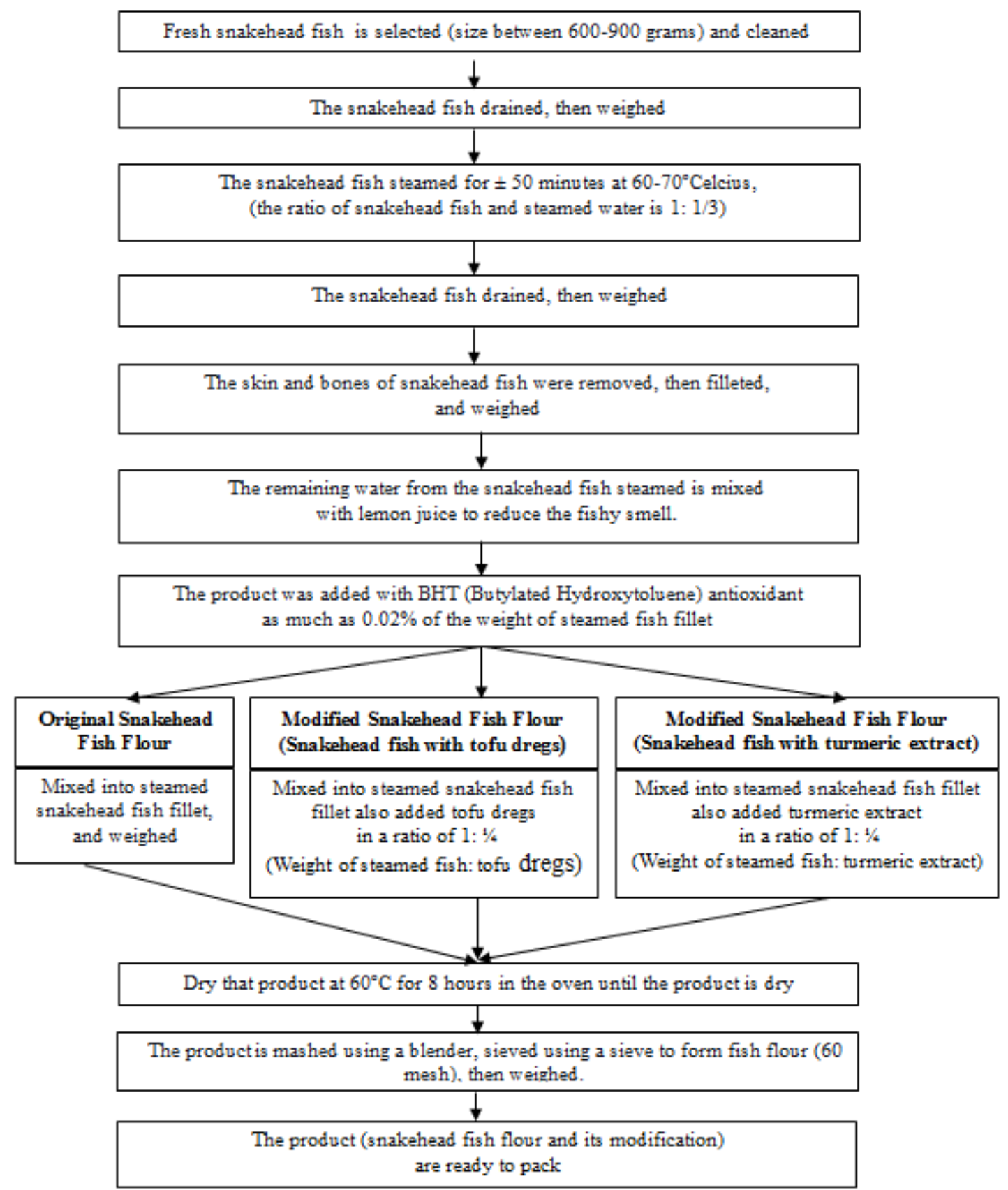

Figure 1. The Porcedure for Making Snakehead Fish Flour (Channa Striata) and Its Modification as Weight Enhancing Supplements for Children with Tuberculosis

Analysis of micronutrients assessed only the content of vitamin $\mathrm{C}$ that used spectrophotometry (Table 1). The result showed that the original snakehead fish flour had the lowest vitamin C content $(0.29 \%)$ compared to the vitamin $\mathrm{C}$ content $(0.35 \%)$ of snakehead fish flour with tofu dregs and vitamin $\mathrm{C}$ content $(0.36 \%)$ of snakehead fish flour with extract turmeric. However, snakehead fish flour showed a higher protein content and energy content than modified snakehead fish meal. Thus, of the three types of flour, the original snakehead fish meal is more suitable for use as a supplement in increasing the weight of children with tuberculosis. However, the other two types of snakehead fish flour can still be used and are recommended as alternative supplements to increase weight in children with tuberculosis.

According to The Fish Flour Quality Requirements according to The SNI 01-2715-1996 (improvement of the revision of SNI 01-2715-1992), in general, the three types of snakehead fish flour meet the Grade I (good) requirements of fish flour (Table 2). But, from the three types of snakehead fish flour, the original snakehead fish flour meets the most criteria of Grade I. The criteria for the quality of fish flour for Grade I that are met include are protein content of $79.62 \%(\min 65 \%), 0.66 \%$ crude 
fiber $(\max 1.5 \%), 5.13 \%$ ash content $(\max 20 \%)$, and $4.93 \%$ fat content $(\max 8 \%)$. Only the water content that does not meet the Grade I criteria is $11.05 \%$ (maximum $10 \%$ ), so that for water content categorized in Grade II.

Table 1. Nutritional Characteristics (Proximate Analysis) of Snakeheaded Fish Flour

\begin{tabular}{|c|c|c|c|c|c|}
\hline \multirow[b]{2}{*}{ Type of Analysis } & \multirow[b]{2}{*}{ Unit } & \multicolumn{3}{|c|}{ Proximate Analysis } & \multirow[b]{2}{*}{ Methods } \\
\hline & & $\begin{array}{l}\text { Original Fish } \\
\text { Flour }\end{array}$ & $\begin{array}{c}\text { Fish Flour }+ \\
\text { Soybean tofu } \\
\text { dregs }\end{array}$ & $\begin{array}{c}\text { Fish flour }+ \\
\text { Turmeric } \\
\text { Extract }\end{array}$ & \\
\hline Water content & $\mathrm{g} / 100 \mathrm{~g}$ & 11.05 & 14.66 & 16.83 & $\begin{array}{c}\text { SNI 01-2891-1992 (Gravimetri); } \\
\text { point } 5.1 \text { [51] }\end{array}$ \\
\hline Ash content & $g / 100 g$ & 5.13 & 7.38 & 7.66 & $\begin{array}{c}\text { SNI 01-2891-1992 (Gravimetri); } \\
\text { point } 6.1\end{array}$ \\
\hline Fat content & $\mathrm{g} / 100 \mathrm{~g}$ & 4.93 & 5.96 & 5.76 & $\begin{array}{l}\text { SNI-01-2891-1992; Point } 8.2 \\
\text { (Hidrolisis-Soxhlet) }\end{array}$ \\
\hline Protein content & $g / 100 \mathrm{~g}$ & $79.62 *$ & $71.11^{*}$ & 71.41 & $\begin{array}{c}\text { IK/01/5.4.1/LDITP/ Protein } \\
\text { Analysis (Micro Kjeldahl) }\end{array}$ \\
\hline Carbohydrates & $\mathrm{g} / 100 \mathrm{~g}$ & 0 & 0.89 & 0 & By difference \\
\hline Crude fiber & $g / 100 g$ & 0.66 & 2.52 & 0.83 & $\begin{array}{l}\text { SNI-01-2891-1992; Point } 11 \\
\text { (Hidrolisis-Soxhlet) }\end{array}$ \\
\hline Energy & $\mathrm{kcal} / 100 \mathrm{~g}$ & 363 & 338 & 337 & $\begin{array}{c}\text { Acoount according to protein } 4 \\
\mathrm{kkal} / \mathrm{g} ; \text { fat } 9 \mathrm{kkal} / \mathrm{g} \text { and } \\
\text { carbohydrat } 4 \mathrm{kkal} / \mathrm{g}\end{array}$ \\
\hline Vitamin C & $\mathrm{g} / 100 \mathrm{~g}$ & 0.29 & 0.36 & 0.36 & Spectrofothometry \\
\hline Albumin & $\%$ & $\begin{array}{c}0.70(0.25 \mathrm{HCL} \\
\text { concentration }(\mathrm{M}) \\
=0.25\end{array}$ & - & - & $\begin{array}{l}\text { High Performance Liquid } \\
\text { Chromatography (HPLC) }\end{array}$ \\
\hline
\end{tabular}

Notes: $*$ Convertion Factors from $\% \mathrm{~N}$ to $\%$ Protein $=6.25$

Table 2. The Fish Flour Quality Requirements according to The Indonesian National Standard: Standar Nasional Indonesia (SNI) 01-2715-1996 (improvement of the revision of SNI 01-2715-1992)

\begin{tabular}{|c|c|c|c|}
\hline Composition & Grade I & Grade II & Grade III \\
\hline Nutritonal Characteristics & & 12 & 12 \\
\hline Water content (\%) maks & 10 & 55 & 3 \\
\hline Crude protein (\%) min & 65 & 2.5 & 30 \\
\hline Crude fiber (\%) maks & 1.5 & 25 & 12 \\
\hline Ash content (\%) maks & 20 & 10 & $2.5-7.0$ \\
\hline Fat content (\%) maks & 8 & $2.5-6.0$ & $1.6-4.7$ \\
\hline Ca content (\%) & $2.5-5.0$ & $1.6-4.0$ & 4 \\
\hline P content (\%) & $1.6-3.2$ & 3 & Negative \\
\hline NaCl content (\%) maks & 2 & Negative & 6 \\
\hline Microbiological Characteristics & Negative & 6 & \\
\hline Salmonella (on 25 gram sample) & & & \\
\hline Organoleptic & 7 & & \\
\hline
\end{tabular}

Source: Standar Nasional Indonesia (SNI) 01-2715-1996 (improvement of the revision of SNI 01-2715- 1992)[33] 


\subsection{Nutritonal Characteristics (Proximate Anaylisis) of Sneakheaded Flour and the Comparison}

Table 3 shows the data regarding the nutritional characteristics of the original snakehead fish flour in this study compared to other snakehead fish flour in the previous studies. The three types of snakehead fish flour are processed using the appropriate methods, which is oven drying. For snakehead fish flour in this study (snakehead fish flour 'A') and snakehead fish flour 'B' were dried at a temperature of $60^{\circ} \mathrm{C}$ for 8 hours. However, when sieving conducted to obtain a smooth texture of snakehead fish flour, the snakehead fish flour 'A' after blending was sieved using a 60-mesh sieve, while the snakehead fish flour 'B' was sieved using an 80-mesh sieve. The processing method is also similar to snakehead fish fluor ' $\mathrm{C}$ ', but the temperature used in drying snakehead fish flour ' $\mathrm{C}$ ' is $40^{\circ} \mathrm{C}$. This temperature is different from drying on snakehead fish flour ' $\mathrm{A}$ ' and snakehead fish flour 'B'.

Table 3 shows the nutritional characteristics of each type of snakehead fish flour. The snakehead fish flour in this study (snakehead fish flour A) showed the highest water content $(11.05 \%)$ compared to snakehead fish flour B (10\%) and snakehead fish flour C (5.68\%). Based on SNI 01-2715-1996 (improvement of SNI 01-2715-1992 revision) in Table 2, the water content of snakehead fish flour A categorized in Grade II, max 12\%). But, snakehead fish flour B and C are included in the Grade I category $(\max 10 \%)$. The ash content for the three types of snakehead fish flour (A, B, and C) included in Grade I (maximum 20\%), namely $5.13 \%, 2.94 \%$, and $6.29 \%$, respectively. Likewise, with the protein content, snakehead fish flour $\mathrm{A}, \mathrm{B}$, and $\mathrm{C}$ are also included in Grade I (minimum 65\%), with the highest to lowest protein content, namely snakehead fish flour B $(86.13 \%)$, snakehead fish flour A (79.62\%), and snakehead fish flour $\mathrm{C}(65.3 \%)$. Of the three types of snakehead fish flour, data on albumin content are only available in snakehead fish flour $\mathrm{A}$, which is $0.7 \%$ albumin extracted using a Hydrochloric Acid (HCL) solvent (concentration of 0.25 M). The highest carbohydrate content in snakehead fish meal $\mathrm{C}$ is $5.27 \%$. There is no carbohydrate content in the snakehead A flour, and the data from the snakehead fish meal $\mathrm{B}$ are not available. Of the three types of flour, snakehead fish flour A met the Grade I criteria (maximum $1.5 \%$ ) for crude fiber $(0.66 \%)$, and snakehead fish flour B had high crudes fiber content (21.83\%). Data are not available on crudes fiber content for the fish flour $\mathrm{C}$. The energy content for the three types of snakehead fish flour was appropriate, namely $363 \mathrm{kcal}, 386 \mathrm{kcal}$, and $386 \mathrm{kcal}$, for snakehead fish flour A, B, and C, respectively.

\subsection{Microbiological Characteristics of Sneakheaded Fish Flour}

Table 4 shows the microbiological characteristics of snakehead fish flour and its modifications. The microbiology characteristics showed that the total plate count was $2.2 \times 105$ colony $/ g$, the total of yeast and mold was $1.5 \times 102$ colony $/ g$, and the total amount of Staphylococcus aureus was $<1.0$ x 101 colony/g.

Table 2 also shows that the three types of flour free from contamination by pathogenic bacteria includes Escherichia coli, Salmonella, and coliform bacteria (0 $\mathrm{MPN} / \mathrm{g}$ ). The microbiologiocal characteristics meet the criteria of flour quality requirementsrefers for Grade I according to SNI 01-2715-1996 (improvement of SNI 01-2715-1992 revision) which stipulates that fish meal must be free from Salmonella contamination (on 25 gram samples).

Table 3. Nutritonal Characteristics (Proximate Anaylisis) of Sneakheaded Flour and the Comparison

\begin{tabular}{|c|c|c|c|c|}
\hline \multirow{2}{*}{ Type of Analysis } & \multirow[b]{3}{*}{ Unit } & \multicolumn{3}{|c|}{ Proximate Analysis of Sneakheaded Fish Flour } \\
\hline & & $\mathbf{A}$ & B & C \\
\hline Methods of Processing & & $\begin{array}{l}\text { Drying with oven, } \\
\text { temperature } 60^{\circ} \mathrm{C} \text {, time }=8 \\
\text { hours } \\
\text { Blend and sifting, }=60 \text { mesh }\end{array}$ & $\begin{array}{ll}- & \text { Drying with cabinet } \\
\text { drier, temperature } \\
60^{\circ} \mathrm{C}, \text { time }=8 \text { hours } \\
\text { Blend and sifting }=80 \\
\text { mesh }\end{array}$ & 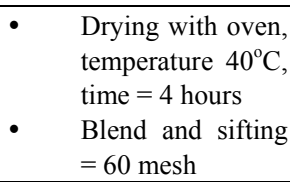 \\
\hline Water level & $\mathrm{g} / 100 \mathrm{~g}$ & 11.05 & 10 & 5.68 \\
\hline Ash level & $\mathrm{g} / 100 \mathrm{~g}$ & 5.13 & 2.94 & 6.29 \\
\hline Fat level & $\mathrm{g} / 100 \mathrm{~g}$ & 4.93 & 13.81 & 2.31 \\
\hline Protein level & $\mathrm{g} / 100 \mathrm{~g}$ & $79.62 *$ & 65.3 & 86.13 \\
\hline Carbohydrates & $\mathrm{g} / 100 \mathrm{~g}$ & 0 & Not Available & 5.27 \\
\hline Crude fiber & $\mathrm{g} / 100 \mathrm{~g}$ & 0.66 & 21.83 & Not Available \\
\hline Energy & $\mathrm{kcal} / 100 \mathrm{~g}$ & 363 & 386 & 386 \\
\hline Albumin & $\%$ & $\begin{array}{c}0.70(0.25 \text { HCL concentration }(\mathrm{M}) \\
=0.25\end{array}$ & Not Available & Not Available \\
\hline
\end{tabular}

Notes: *Convertion Factors from $\% \mathrm{~N}$ to $\%$ Protein $=6.25 ; \mathrm{A}=$ Snakeheaded Fish Flour in this study; $\mathrm{B}=$ Study by Wirawan, Alaydrus, and Nobertson[52]; C = Study by Mahardika, Karnila and Edison [53] 
Table 4. Micribiological Characteristics of Snakeheaded Fish Flour

\begin{tabular}{|c|c|c|l|}
\hline Type of Analysis & Unit & Results & \multicolumn{1}{|c|}{ Methods } \\
\hline Total plate count & Colony/g & $2.2 \times 10^{5}$ & $\begin{array}{l}\text { IK/18/7.2/LDITP/Analysis of Total plate count } \\
35^{\circ} \mathrm{C} \text { (The plate count methods) }\end{array}$ \\
\hline Total of yeast and mold & Colony/g & $1.5 \times 10^{2}$ & $\begin{array}{l}\text { BAM Chapter 18, January 2001 (plate count } \\
\text { methods) }\end{array}$ \\
\hline Salmonella & - & Negative & $\begin{array}{l}\text { BAM Chapter 5, November 2019 (Isolation and } \\
\text { identification) }\end{array}$ \\
\hline Escherichia coli & MPN/g & Negative & $\begin{array}{l}\text { IK/14/7.2/LDITP/Analyisis of Eschericia coli } \\
\text { (MPN methods, isolation and identification) }\end{array}$ \\
\hline Total of Staphylococcus aureus & Colony/g & $<1.0 \times 10^{1}$ & $\begin{array}{l}\text { BAM Chapter 21, January 2001 (plate count } \\
\text { methods) }\end{array}$ \\
\hline Coliform & MPN/g & $\begin{array}{l}\text { BAM Chapter 4, January 2001 (plate count } \\
\text { methods) }\end{array}$ \\
\hline
\end{tabular}

\section{Discussion}

\subsection{Yield and Rendemen of Snakeheaded Fish}

The production of snakehead fish (Channa striata) in Indonesia has increased significantly from 6,490 tons in 2015 to increase in 2019 to 21,987 tons [54]. Channa striata is included in one of four species of snakehead fish from the Channa genus, namely Channa striata, Channa micropeltes, Channa lucius, and Channa pleuropthalamus. The morphological characteristic of this fish is that it has a round, cylindrical body shape, slightly black, and weighs up to $250 \mathrm{~g} /$ fish [55]. This freshwater fish can be cultivated easily. The processing technology of snakehead fish is growing rapidly in line with the high demand of the community in consuming snakehead fish which has economic value and health benefits. Snakehead fish contains high protein and albumin, so it is the potential to be used as a supplement in accelerating the treatment of children with tuberculosis especially to increase their body weight and immunity [56][57]. Previous studies have shown that using organoleptic tests, various processed foods made from snakehead fish are liked by the public [52][56][58]. In addition, snakehead fish has more meat than similar fish such as catfish. This study shows that that snakehead fish has a yield of about $2.38-2.97 \%$, and an edible portion of snakehead fish ranged from $50.35-55.12 \%$. The results of this study indicate that the edible portion of snakehead fish $(50.35-55.12 \%)$ is higher than catfish (around 40\%) [59]. This is due to the size of snakehead fish which is generally larger than catfish. The size of snakehead fish is categorized into three groups, namely small $(<600 \mathrm{~g})$, medium (600-900 g), and large ( $>900 \mathrm{~g})$ sizes [31]. In this study, the snakehead fish chosen was medium-sized, weighing between 600-900 grams (medium size). The use of snakehead fish with a smaller size $(<600 \mathrm{~g})$, causes a less edible portion. Meanwhile, the use of snakehead fish with a larger size $(>900 \mathrm{~g})$ requires a higher temperature and a longer time during the steaming process [31].

A study by Asikin and Kusumaningrum in 2018 showed that the not much difference for the yield of snakehead fish varied between $2.50-2.93 \%$ and edible portion ranged of $49.8-54.73 \%$. The material used in that study was snakehead fish with different species, namely Ophiocephalus striatus with various size variations (less than 600 grams to more than $>900 \mathrm{~g}$ ). This snakehead fish is native snakehead fish, where the fish was obtained from the catch, in the watershed of the Middle Mahakam River (Muara Muntai and Kotabangun), Kutai Kartanegara regency, East Kalimantan, Indonesia [31]. The Ophiocephalus striatus living in nature (native snakehead fish) while the Channa striata used in this study was cultured snakehead fish [60]. In line with another study shows that snakehead fish that lives naturally in rivers (native snakehead fish) and cultured snakehead fish has an edible portion that is not much different, namely $38.0 \%$ and $35.9 \%$, respectively. However, although the environment of the two types of snakehead fish is different because the edible portion (EP) is not only influenced by the availability of food, but also by other factors including sex, age, and heredity, where it was reported that female snakehead fish was reported to have higher edible portion than male fish [40].

\subsection{Nutritional Characteristics of Original Snakehead Fish Flour and Its Modification}

The results of this study indicate that the original snakehead fish flour and the modified snakehead fish flour meet the most criteria of Grade I for nutritional characteristics, according to The Fish Flour Quality Requirements in SNI 01-2715-1996 (improvement of the revision of SNI 01-2715-1992). But even so, of the three types of flour that best meets the Grade I requirements for the fish flour quality is the original snakehead fish flour. The criteria for the quality of fish flour for Grade I that are met include are protein content of $79.62 \%(\min 65 \%)$, $0.66 \%$ crude fiber $(\max 1.5 \%), 5.13 \%$ ash content ( $\max$ $20 \%$ ), and $4.93 \%$ fat content $(\max 8 \%)$. Only the water content that does not meet the Grade I criteria is $11.05 \%$ (maximum 10\%), so that for water content categorized in Grade II.

The water content in the original snakehead fish meal 
was the lowest compared to the two types of modified fish meal. The highest water content was snakehead fish flour with turmeric extract (14.66\%), followed by water content in snakehead fish flour with tofu dregs (16.83\%). The water content of tofu dregs and turmeric extract before mixed with snakehead fish is high, between $60-85 \%$. The others technologies used to reduce the water content are rotary dryer, spray dryer, freeze dryer, and tray dryer. These drying technologies can increase the temperature and airflow velocity, and the drying process is faster $[61][62][63]$. The findings of this study also indicate that the original snakehead has low carbohydrates $(0 \%)$ and fat content $(4.93 \%)$ compared with the two types of modified snakehead fish flour, where meet the quality criteria of Grade I fish flour based on SNI 01-2715-1996 (improvement of SNI 01-2715-1992 revision). In line with previous studies, that snakehead fish has a low fat and carbohydrate content [30][40]. The original snakehead fish flour has the highest energy content $(363 \mathrm{kcal})$ compared with snakehead fish flour with tofu dregs (338 kcal) and snakehead fish flour with turmeric extract (337 kcal). Children with tuberculosis, especially those who are malnourished, need sufficient energy to meet their daily needs. The infection of Mycobacterium tuberculosis can cause low appetite, malabsorption of nutrients, and wasteful metabolism. Conversely, malnutrition can worsen the immunity of children with tuberculosis. Therefore, the adequate nutritional intake and consumption of snakehead fish as weight enhancing supplements can optimize children with tuberculosis treatment [25][26].

Snakehead fish (Channa striata) is a freshwater fish that contains high protein and albumin, which is a prospective alternative for nutraceutical products [29][30]. Based on this study, the original snakehead fish has high protein content $(79.62 \%)$ and contained $0.7 \%$ albumin (extracted using an HCL solvent at a concentration of 0.25 M). Meanwhile, the protein content of modified snakehead fish flour is lowest than original snakehead fish flour, namely snakehead with tofu dregs (71.11\%) and snakehead with turmeric extract $(71.41 \%)$, because the composition of the snakehead fish flour is pure, without any other materials. The protein content in snakehead fish is higher than tofu dregs [30] and turmeric extract [61]. A study by Nurilmala reported that protein content in fresh snakehead fish extract was $11.62 \pm 0.17 \mathrm{mg} / \mathrm{g}$, boiled $6.28 \pm 0.57 \mathrm{mg} / \mathrm{g}$, and pure $105.23 \pm 0.44 \mathrm{mg} / \mathrm{g}$. Other studies by Asikin and Kusumaningrum have shown that snakehead fish for various size categories, namely category I ( $<600 \mathrm{~g})$, II (600-900 g), and III ( $>900 \mathrm{~g})$, have protein and albumin content of $59.24 \%$ and $15.26 \%$; $63.33 \%$ and $17.85 \%$, and $63.59 \%$ and $14.23 \%$, respectively [62]. The protein content of snakehead fish flour $(79.62 \%)$ in this study was higher compared to studies conducted by Asikin and Kusumaningrum (59.24-63.59\%). But in this study, albumin content was lower $(0.7 \%)$ than the study by Asikin and Kusumaningrum (14,23-17,85\%). The difference in nutritional content (albumin content) can be caused by snakehead fish processing methods. In this study, snakehead fish was steamed for a longer time, which was about 50 minutes at $60-70^{\circ}$ Celcius, while in the Asikin and Kusumaningrum studies, the heating is conducted for 15 minutes at $60^{\circ} \mathrm{C}$ [31].

\subsection{Nutritional Characteristics of Original Snakehead Fish Flour and the Comparison}

The nutritional characteristics of the three types of snakehead fish flour (snakehead fish flour A, snakehead fish flour B, and snakehead fish flour C) have some similarities and differences based on the SNI 01-2715-1996 (improvement of SNI 01-2715-1992 revision) about fish flour quality requirements. Of the three types of flour, snakehead fish flour $\mathrm{C}$ had better nutritional content than snakehead fish flour A and B. Snakehead fish flour $\mathrm{C}$ has lower water content $(5.68 \%)$ and fat content $(2.31 \%)$ than snakehead fish flour A and snakehead fish flour B. Also, it has high energy content (386 kcal) and protein content $(86.13 \%)$. Although the ash content of snakehead fish flour $\mathrm{C}$ is the highest $(6.29 \%)$ compared to fish flour A $(5.13 \%)$ and B $(2.94 \%)$, this figure meets the Grade I category ( $20 \%$ maximum). The difference in the characteristics of the superior nutritional content of snakehead fish flour $\mathrm{C}$ compared to snakehead fish flour A and B is caused by differences in temperature and duration of the drying process, where the drying process is conducted at a lower temperature $\left(40^{\circ} \mathrm{C}\right)$ and a shorter drying time of 4 hours. Snakehead fish flour A and $\mathrm{B}$ are dried at a temperature of $60^{\circ} \mathrm{C}$ for 8 hours. Drying is a method for removing or removing part of the water from the material by evaporating the water using heat energy. The higher temperature and time of the snakehead fish drying process can cause a decrease in the quality of the nutritional content, especially protein and albumin in snakehead fish [30][48][64]. The snakehead fish flour ' $\mathrm{C}$ ' has the highest protein content $(86.13 \%)$ compared with snakehead fish flour A and snakehead fish B. The drying process with a high temperature and a long time can reduce the quantity and quality of protein. The heating process in fish processing can cause protein denaturation, which is the occurrence of changes in the basic conformation of proteins. Also, it can cause the formation of cross-linkages between protein amino acids. Therefore, setting the high temperature and drying process needs to maintain the nutritional characteristics of snakehead fish, which will use as supplements and other health products [30][48][50].

A study by Nugroho reported that the combination of temperature and steaming time affected the albumin content of snakehead fish. The steaming process by a water bath with $40-90 \mathrm{oC}$ for 25-35 minutes can cause the lower albumin content. Heating the snakehead fish to a 
temperature of $90^{\circ} \mathrm{C}$ for 20 minutes causes the albumin structure to be irreversible, which is indicated by the increase in the surface of the non-polar protein and changes in its functional properties. The study also found that the highest albumin yield of snakehead fish extract

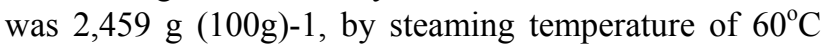
for 25-35 minutes [31]. The albumin content of snakehead fish is relatively higher than that of other fish. Albumin is the main protein that is abundant in blood plasma. In addition, the quality of essential and non-essential amino acids in snakehead fish is also better than other sources of animal protein such as eggs and other poultry products [48][24]. The types of proteins found in fish are sarcoplasmic, myofibril, and stromal proteins. Albumin is a type of sarcoplasmic protein that has some function in new cell tissue formation, accelerates the recovery of damaged cell tissue, and maintains fluid balancing in the vascular cavity with the fluid in the interstitial cavity [40]. An experimental study in Indonesia proved that giving snakehead fish (Channa striata) supplementation to tuberculosis patients can increase BMI faster than TB patients who are not given snakehead fish supplements for one month, with minimal worse effects. Therefore, the consumption of snakehead fish supplements is highly recommended for children with tuberculosis to accelerate tuberculosis treatment [30].

\subsection{Microbiological Characteristics of Sneakheaded Fish Flour}

The results of this study indicate that the three types of snakehead fish flour (original snakehead fish flour, snakehead fish flour with tofu dregs, and snakehead fish flour with turmeric extract) were free from contamination by pathogenic bacteria. These microbiological characteristics meet the criteria GradeI of fish flour quality requirements according to SNI 01-2715-1996 (improvement of SNI 01-2715-1992 revision), which stipulates that fish flour must be free from Salmonella contamination (on $25 \mathrm{~g}$ samples) [33]. A study by Hidayati et al (2018), shows that processing snakehead fish extract using a heating process below $60 \mathrm{oC}$ has a risk of pathogenic microorganism contamination such as Escherichia coli, if not immediately stored in freezing temperature after production production [65].

The users of this snakehead fish supplement are children with tuberculosis as the age group at risk. Consequently, it must be guaranteed to be free of all forms of contamination include physical, chemical, and microbiological contamination. Microbiological criteria for food products define are the quality of a food product that is assessed based on the presence or absence of the number of microorganisms, including parasites and/or the number of toxins/metabolites per unit mass, volume, area, or lot. The control process of microorganisms in food is demonstrated by microbiological testing of samples at various stages. The results compared with criteria are developed to assure that the food is safe and of good quality. The prevention for food quality assurance is the Hazard Analysis Critical Control Point (HACCP) principle, at all steps in the food supply and processing system. Several regulations that define microbiological criteria are regulations by the Codex Alimentarius Commission (CAC, 2001) and the EU Scientific Committee for Food (EU, 1997) [66].

\section{Conclusions}

The original snakehead fish and modified snakehead fish flour (snakehead fish flour with tofu dregs and snakehead fish flour with turmeric extract) have met the quality requirements for a fish meal based on SNI 01-2715-1996 (improvement of SNI 01-2715- 1992 revision). In general, the three types of snakehead fish flour in this study meet the Grade I criteria (nutritional and microbiological characteristics). So that, the three snakehead fish flour can recommend being used as a weight enhancing supplement for children with tuberculosis. But, several stages include organoleptic and experimental research, need to be done to prove the effectiveness of these supplements on weight gain in children with tuberculosis. Among the three types of snakehead fish flour, the original snakehead flour meets the criteria closest to Grade I. However, better processing technology for snakehead fish supplements is needed to improve the quantity and quality of nutritional content, especially protein and albumin content and microbiological characteristics. One of the recommended technologies is freeze-drying which can maintain the protein and albumin content in snakehead fish flour. Furthermore, prevention and control are necessary for every stage in making snakehead fish supplements using the Hazard Analysis Critical Control Point (HACCP) for food quality assurance.

\section{Acknowledgements}

The authors give the highest appreciation to the Ministry of Research and Technology of the Republic of Indonesia, who has provided this research grant. Outr thanks also go to Research Institutions and Community Services, Universitas Muhammadiyah Jakarta (Lembaga Penelitian dan Pengabdian kepada Masyarakat, Universitas Muhammadiyah Jakarta) which has facilitated the implementation of this research. We are grateful to the three faculties at the Universitas Muhammadiyah Jakarta, namely the Faculty of Nursing Science, the Faculty of Medicine and Health, and the Faculty of Engineering that have collaborated in carrying out research that is beneficial to the development of science. 


\section{Funding}

This research was funded by the Ministry of Research and Technology of the Republic of Indonesia (grant number 74/R-UMJ/VII/2020). The Ministry of Research and Technology of the Republic of Indonesia funded for all funding used in research includes the provision of materials and tools, analysis of nutrients and microbiology, publications, and other needs that support this research.

\section{REFERENCES}

[1] World Health Organization. "Global Tuberculosis Report 2020; WHO: Geneva, Switzerland, 2020." (2020).

[2] W. H. O. Global dan T. B. Programme, "Tuberculosis and COVID-19."

[3] E. Mohr-Holland et al., "Tuberculosis preventive therapy for children and adolescents: an emergency response to the COVID-19 pandemic," Lancet Child Adolesc. Heal., Vol. 5, No. 3, pp. 159-161, 2021.

[4] D. Visca et al., "Tuberculosis and COVID-19 interaction: A review of biological, clinical and public health effects," Pulmonology, Vol. 27, No. 2, pp. 151-165, 2021.

[5] L. Grobler, S. Durao, S. M. Van der Merwe, J. Wessels, dan C. E. Naude, "Nutritional supplements for people being treated for active tuberculosis: A technical summary," S. Afr. Med. J., Vol. 108, No. 1, pp. 16-18, 2017.

[6] World Health Organization, Roadmap towards ending TB in children and adolescents. Second edition. 2018.

[7] P. Sinha et al., "Undernutrition and Tuberculosis: Public Health Implications,” J. Infect. Dis., Vol. 219, No. 9, pp. 1356-1363, 2019.

[8] P. Sinha et al., "Food for thought: addressing undernutrition to end tuberculosis," Lancet Infect. Dis., 2021.

[9] N. A. Tellez-Navarrete, L. A. Ramon-Luing, M. Muñoz-Torrico, I. A. Osuna-Padilla, dan L. Chavez-Galan, "Malnutrition and tuberculosis: the gap between basic research and clinical trials," J. Infect. Dev. Ctries., Vol. 15, No. 03,pp. 310-319, 2021.

[10] E. Rita, I. N. Saputri, G. Widakdo, T. A. E. Permatasari, dan I. Kurniaty, "Contact History And Poor Nutritional Status Csn Increase The Incidence Of Tuberculosis In Children (Case Study on Adult Contacts of Adult Tuberculosis Patients)," J. Kesehat. Masy. Khatulistiwa, Vol. 7, No. 1, pp. 20-29, 2020. (in Indonesian)

[11] Tria Astika Endah Permatasari, and Amir Syafruddin. "Early initiation of breastfeeding related to exclusive breastfeeding and breastfeeding duration in rural and urban areas in Subang, West Java, Indonesia." Journal of Health Research, Vol. 30, No. 5, pp. 337-345, 2016.

[12] Tria Astika Endah Permatasari, et al. "Exclusive breastfeeding intention among pregnant women." Kesmas: Jurnal Kesehatan Masyarakat Nasional (National Public Health Journal), Vol. 12, No. 3, pp. 134-141, 2018.
[13] T. A. E. Permatasari, N. W. Sudiartini, "Do health workers play a role in exclusive breastfeeding among working mothers in industrial area?," J. Nutr. Sci. Vitaminol., Vol. 66, pp. S94-S98, 2020.

[14] T. A. E. Permatasari, W. Widjajanti, A. Sunarto, Andriyani, A. I. Ramadhan, "Factors related to the granting of colostrum in newborn baby with caesarean section in hospital government at Banten, Indonesia," Food Sci. Technol., Vol. 8, No. 3, pp. 61-72, 2020. DOI: $10.13189 /$ fst.2020.080303.

[15] S. S. Chiang et al., "Using changes in weight-for-age $\mathrm{z}$ score to predict effectiveness of childhood tuberculosis therapy," J. Pediatric Infect. Dis. Soc., Vol. 9, No. 2, pp. 150-158, 2020.

[16] Y. Ko, C. Kim, Y. B. Park, E.-K. Mo, J.-W. Moon, "Changes in Nutritional Status in Pulmonary Tuberculosis: Longitudinal Changes in BMI According to Acid-Fast Bacilli Smear Positivity," J. Clin. Med., Vol. 9, No. 12, pp. 4082, 2020.

[17] World Health Organization, "Guideline : Nutritional care and support for patients with tuberculosis," World Heal. Organ., pp. 54, 2013.

[18] G. Praygod et al., "The effect of energy-protein supplementation on weight, body composition and handgrip strength among pulmonary tuberculosis HIV-co-infected patients: Randomised controlled trial in Mwanza, Tanzania," Br. J. Nutr., Vol. 107, No. 2, pp. 263-271, 2012.

[19] Z. Ren et al., "Nutritional intakes and associated factors among tuberculosis patients: A cross-sectional study in China,” BMC Infect. Dis., Vol. 19, No. 1, pp. 1-8, 2019.

[20] Amir Syafruddin, Tria Astika Endah Permatasari, Anwar Ilmar Ramadhan, "Analysing the Relationship of Mini Student Oral Case Analysis (SOCA) Test and Mini Objective Structured Clinical Examination (OSCE) with the National Doctor Professional Competency Test in Indonesia", International Journal of Innovation, Creativity and Change, Vol. 11, No. 12, pp. 668-674, 2020.

[21] U. Grohmann et al., "Amino-acid sensing and degrading pathways in immune regulation," Cytokine Growth Factor Rev., vol. 35, hal. 37-45, 2017.

[22] F. Bifari, C. Ruocco, I. Decimo, G. Fumagalli, A. Valerio, dan E. Nisoli, "Amino acid supplements and metabolic health: a potential interplay between intestinal microbiota and systems control," Genes Nutr., Vol. 12, No. 1, pp. 1-12, 2017.

[23] S. J dan B. Y, "Serum Albumin/Globulin ratio in Tuberculosis and HIV Patients any Relationship?," Mycobact. Dis., Vol. 6, No. 1, hal. 1-6, 2016.

[24] R. M. Rosyidi, J. Januarman, B. Priyanto, A. A. Islam, M. Hatta, dan A. Bukhari, "The Effect of Snakehead Fish (Channa striata) Extract Capsule to the Albumin Serum Level of Post-operative Neurosurgery Patients," Biomed. Pharmacol. J., Vol. 12, No. 2, pp. 893-899, 2019.

[25] I. Ma, K. Ali, I. A. Sedemen, P. Purwanto, dan A. Khoiri, "Channa striata (Ikan Gabus) Extract and the Acceleration of Tuberculosis Treatment: A True Experimental Study," Vol. 2019, 2019. 
[26] I. Ma’Rufi, K. Ali, S. K. Jati, A. Sukmawati, K. Ardiansyah, dan F. W. Ningtyias, "Improvement of Nutritional Status among Tuberculosis Patients by Channa striata Supplementation: A True Experimental Study in Indonesia," Biomed Res. Int., 2020.

[27] H. A. Pratama, E. Efendi, dan R. Riyanti, "Pengaruh Ekstrak Albumin Ikan Gabus (Channa striata) terhadap Kadar IFN- $\gamma$ Pasien Tuberkulosis Paru dengan Pengobatan Fase Intensif," e-Jurnal Pustaka Kesehat., Vol. 4, No. 2, pp. 222-228, 2016. (in Indonesian)

[28] I. Kurniaty, E. Rita, G. Widakdo, T. A. E. Permatasari, M. Dwiyanti, "Isolation Of Snake-Head (Channa striata) Albumin Using Variation Concentration Of Hydrochloric and Citric Acid," 2019.

[29] C. Prastari1, S. Yasni, M. Nurilmala, "Karakteristik Protein Ikan Gabus Yang Berpotensi,", JPHPI, Vol. 20, pp. 413423, 2017. (in Indonesian)

[30] D. Teknologi et al., "Profil Protein Ikan Gabus (Channa striata), Toman (Channa micropeltes), dan Betutu (Oxyeleotris marmorata):," J. Pengolah. Has. Perikan. Indones., Vol. 23, No. 3, pp. 548-557, 2020. (in Indonesian)

[31] A. N. Asikin, I. Kusumaningrum, "Karakteristik Ekstrak Protein Ikan Gabus Berdasarkan Ukuran Berat Ikan Asal DAS Mahakam Kalimantan Timur," J. Pengolah. Has. Perikan. Indones., vol. 21, no. 1, hal. 137, 2017. (in Indonesian)

[32] R. Sholihah, A. H. Santoso, dan I. K. Suwita, "Formulasi tepung ikan gabus," Vol. 3, No. 2, pp. 132-144, 2017. (in Indonesian)

[33] L. Assadad, A. R. Hakim, T. N. Widianto, E. Erlania, "Standar ini meliputi definisi, klasifikasi, persyaratan mutu, cara pengemasan, cara pengambilan contoh dan metode analisis 2.," Semin. Nas. Tah. XII Has. Penelit. Perikan. dan Kelaut., Vol. 1996, No. 1, pp. 3178, 1996. (in Indonesian)

[34] A. Suhendi, H. Pawarti, A. Rohman, dan D. Wahyono, "Snakehead fish extract (Channa striata): A review of pharmacological activity," EurAsian J. Biosci., vol. 4533, no. November 2019, hal. 4527-4533, 2020.

[35] Pusat Data dan Informasi Kesehatan Republik Indonesia, Kementerian Kesehatan Republik Indonesia, "Tuberkulosis (TB)," Tuberkulosis, Vol. 1, 2018. (in Indonesian)

[36] Yoga Ginanjar, Tria Astika, dan Nana Supriyatna, “Analisis Pengaruh Psikososial Dan Faktor Resiko Lainya Terhadap Kejadian Tb Mdr," Bina Gener. J. Kesehat., Vol. 11, No. 1, pp. 46-54, 2019. (in Indonesian)

[37] Maharani, Rahayu, Nyimas Heny Purwati, and Tria Astika Endah Permatasari. "Screening for Malnutrition and the Effect of Education Using the STRONGkids Application on Increasing Mother's Knowledge and Children's Eating Behavior." The International Journal of Social Sciences World (TIJOSSW)., Vol. 2, No 2, pp. 144-152, 2020.

[38] T. A. E. Permatasari, F. Rizqiya, W. Kusumaningati, I. I. Suryaalamsah, dan Z. Hermiwahyoeni, "The effect of nutrition and reproductive health education of pregnant women in Indonesia using quasi experimental study," BMC Pregnancy Childbirth, Vol. 21, No. 1, pp. 1-15, 2021.
[39] Kemenkes RI, "Hasil Riset Kesehatan Dasar Tahun 2018," Kementrian Kesehat. RI, Vol. 53, No. 9, pp. 1689-1699, 2019. (in Indonesian)

[40] E. Chasanah, M. Nurilmala, A. R. Purnamasari, and D. Fithriani, "Komposisi Kimia, Kadar Albumin Dan Bioaktivitas Ekstrak Protein Ikan Gabus (Channa Striata) Alam Dan Hasil Budidaya," J. Pascapanen dan Bioteknol. Kelaut. dan Perikan., Vol. 10, No. 2, hal. 123, 2015. (in Indonesian)

[41] D. S. Mulia, E. Yulyanti, H. Maryanto, dan C. Purbomartono, "Peningkatan kualitas ampas tahu sebagai bahan baku pakan ikan dengan fermentasi Rhizopus oligosporus," Sainteks, Vol. 12, No. 1, pp. 10-20, 2015. (in Indonesian)

[42] F. N. Rachma, S. Hidanah, M. S. Sofyan, dan B. Setiawan, "The Potency of Dry-Cooked Rice Waste and Tofu Dregs on Weight Gain and Feed Conversion in Beef Cattle," J. Appl. Vet. Sci. Technol., Vol. 1, No. 2, pp. 48, 2020.

[43] J. Permadi, D. Sukmarani, dan M. Mudiyono, "Pengaruh Kadar Ampas Tahu Pada Pakan Ikan Gabus Channa gachua Terhadap Kadar Albumin Daging,” Biog. J. Ilm. Biol., Vol. 5, No. 1, pp. 7-12, 2017. (in Indonesian)

[44] J. Sharifi-Rad et al., "Turmeric and Its Major Compound Curcumin on Health: Bioactive Effects and Safety Profiles for Food, Pharmaceutical, Biotechnological and Medicinal Applications," Front. Pharmacol., Vol. 11, September, pp. $1-23,2020$

[45] S. Hewlings dan D. Kalman, "Curcumin: A Review of Its Effects on Human Health," Foods, Vol. 6, No. 10, pp. 92, 2017.

[46] Y. C. Zanzer, Â. G. Batista, A. Dougkas, J. Tovar, Y. Granfeldt, and E. Östman, "Difficulties in translating appetite sensations effect of turmeric-based beverage when given prior to isoenergetic medium- or high-fat meals in healthy subjects," Nutrients, Vol. 11, No. 4, pp. 1-7, 2019.

[47] U. Chasanah dan R. W. Nugraheni, "Pengaruh Metode Ekstraksi terhadap Kadar Albumin Ekstrak Ikan Gabus (Channastriata)," Pros. Rapat Kerja Fak. Ilmu Kesehat. 2017 Pros. Peningkatan Keilmuan Solusi Tantangan Profesi Kesehat., 2017. (in Indonesian)

[48] M. Nugroho, "Pengaruh Suhu Dan Lama Ekstraksi Secara Pengukusan Terhadap Rendemen Dan Kadar Albumin Ikan Gabus (The Effect of Temperature and Duration of the Steaming Extraction Albumin Content and Yield from the Fish Gabus (Ophiocephalus striatus))," SAINTEK Perikan. Indones. J. Fish. Sci. Technol., Vol. 8, No. 2, pp. 38-43, 2013. (in Indonesian)

[49] S. Puwaningsih, E. Salamah, dan Riviani, "Kandungan Taurin Ikan Glodok (Periopthalmodon schlosseri) Th e Changing of Chemical Composition, Amino Acids, and Taurine Content at Glodok Fish (Periopthalmodon schlosseri)," Jphpi, Vol. 16, No. 1, pp. 12-21, 2013. (in Indonesian)

[50] S. Salmatia, K. Isamu, dan A. Sartinah, "Pengaruh Proses Perebusan dan Pengukusan terhadap Kandungan Albumin dan Proksimat Ikan Gabus (Channa striata)," J. Fish Protech, Vol. 3, No. 1, pp. 67-73, 2020. (in Indonesian)

[51] S. Nasional dan B. S. Nasional, "Cara Uji Makanan dan 
Minuman," SNI (Standar Nasional Indonesia, 1992. (in Indonesian)

[52] I. Gabus, S. Bahan, dan D. Olahan, "Analisis Karakteristik Kimia Dan Sifat Organoleptik Tepung Ikan Gabus Sebagai Bahan Dasar Olahan Pangan," J. Sains dan Kesehat., Vol. 1, No. 9, pp. 479-483, 2018. (in Indonesian)

[53] N. Mahardika, R. Karnila, Edison, "Analysis Of Meat Chemical Composition And Fish Meal From Snakehead Fish (Channa striata). Universitas Riau. 2020

[54] Kementerian Kelautan dan Perikanan. "Produksi Perikanan: Data Statitik Produksi Ikan Gabus. 2019. https://statistik.kkp.go.id/home.php?m=total\&i=2." (accessed on: 22 November 2019) (in Indonesian)

[55] M. Muslim, "Jenis-Jenis Ikan Gabus (Genus Channa) di Perairan Rawa Banjiran Sungai Kelekar Indralaya Ogan Ilir Sumatera Selatan," Pros. Semin. Jur. Biol. FMIPA UNPAD Bandung, 22 Oktober 2013, Oktober, pp. 241-249, 2013. (in Indonesian)

[56] Leni Anggraini, and Andriani. "Kualitas kimia dan organoleptik nugget ikan gabus melalui penambahan tepung kacang merah." Jurnal SAGO Gizi dan Kesehatan, Vol. 2, No. 1, pp. 11-18, 2020. (in Indonesian)

[57] M. Muslim, “Teknologi pembenihan ikan gabus (Channa striata)," J. Ruaya J. Penelit. dan Kaji. Ilmu Perikan. dan Kelaut., Vol. 7, No. 2, pp. 21-25, 2019. (in Indonesian)

[58] S. Jeujanan, "Uji Mutu Kerupuk Ikan Gabus (Channa striata) Secara Organoleptik Yang Diolah Kelompok Sentani Barokah di Kabupaten Jayapura (Organoleptic Quality Test Of Cork Fish (Channa striata) Cracker Managed by Sentani Barokah Group in Jayapura District)", Agricola, Vol. 10, No. 1, pp. 50-57, 2020. (in Indonesian)

[59] Dyah Ilminingtyas Wahyu Handayani, and Diah Kartikawati. "Stiklele alternatif diversifikasi olahan lele
(Clarias SP) tanpa limbah berkalsium tinggi." Serat Acitya, Vol. 4, No. 1, pp. 109, 2015. (in Indonesian)

[60] Muhammad Briliandar Saputra, Ade Dwi Sasanti, and Yulisman. "Pengaruh Perbedaan Jenis Pakan terhadap Kandungan Albumin dan Kelangsungan Hidup Ikan Gabus (Channa striata)." Seminar Nasional Lahan Suboptimal. 2019. (in Indonesian)

[61] K. Budaarsa, et al. "Pemanfaatan ampas tahu untuk mengganti sebagian ransum komersial ternak babi." Jurnal Ilmiah Peternakan Universitas Udayana, Vol. 18, No. 1, 2015. (in Indonesian)

[62] Muhaeminan, Sri Haryati, and Maria Sudjatinah. "Berbagai Konsentrasi Ekstrak Kunyit Terhadap Sifat Fisikokimia Dan Organoleptik Fillet Ikan Bandeng Selama Penyimpanan 24 Jam." Jurnal Teknologi Pangan dan Hasil Pertanian, Vol. 13, No. 2, pp. 47-57, 2018. (in Indonesian)

[63] Y. I. Nofriati, "Uji Kinerja Pengontrol Suhu Pengering Mekanis Tipe Rak (Tray Dryer) Sebagai Alat Penunjang Di Laboratorium," J. TEMAPELA, Vol. 1, No. 2, pp. 56-61, 2018. (in Indonesian)

[64] E. Abustam, Rosmawati,, A. B. Tawali, M. I. Said, dan D. K. Sari, "Chemical Composition, Amino Acid and Collagen Content of Snakehead (Channa striata) Fish Skin and Bone," Sci. Res. J., Vol. 6, No. 1, pp. 1-4, 2018.

[65] D. Hidayati, N. Jadid, E. Nugroho, N. Abdulgani, N. H. Alami, dan D. A. C. Putri, "Microbiological evaluation and storage stability of snakehead fish extract (Channa striata) using steaming method," Curr. Res. Nutr. Food Sci., Vol. 6, No. 2, pp. 520-525, 2018.

[66] John Ryder, Karunasagar Iddya, and Lahsen Ababouch. "Assessment and management of seafood safety and quality: current practices and emerging issues." FAO fisheries and aquaculture technical paper 574, 2014. 